\title{
The Influence of Solar Radiation on the Antioxidant Systems in Blood of Dairy Cows and Their Correlations with Milk Quality and Quantity
}

Dana PUSTA ${ }^{1}$, Rodica SOBOLU ${ }^{2}$, Sanda ANDREI ${ }^{3}$, Camelia RADUCU $^{4}$, Ioana POP ${ }^{2}$, Alexandra TĂBĂRAN ${ }^{1}$, Oana REGET ${ }^{1}$, Mihai BORZAN ${ }^{1}$, Ioan PAȘCA ${ }^{1}$

${ }^{1}$ Department of Animal Productions and Food Safety, Faculty of Veterinary Medicine,

${ }^{2}$ Department of Terrestrial Measurements and Exact Sciences, Faculty of Horticulture,

${ }^{3}$ Department of Preclinical Sciences, Faculty of Veterinary Medicine,

${ }^{4}$ Department II, Faculty of Animal Husbandry,

University of Agricultural Sciences and Veterinary Medicine, Cluj-Napoca, Romania

*corresponding author: rodica.sobolu@usamvcluj.ro

Bulletin UASVM Veterinary Medicine 75(1)/2018

Print ISSN 1843-5270; Electronic ISSN 1843-5378

doi:10.15835/buasvmcn-vm:005917

\begin{abstract}
The purpose of this paper is to observe if in cattle, exposed to the solar radiation, could be noticed a certain reaction of the organism related to the oxidative stress and its influence on milk quantity and quality. During the hot summer days, when the values of THI exceed 72, the oxidative stress is produced in dairy cows, which is mainly manifested till the cellular level, by the increasing of the antioxidant enzymes activity. There was recorded a direct corelation between the increasing of the antioxidant enzymes level and the increasing of the THI.
\end{abstract}

Keywords: antioxidant enzymes, dairy cows, milk quality and quantity, solar radiation

\section{Introduction}

This paper presents some of the results belonging to a larger study which wants to find out if the milking cows are submitted to the heat stress induced by the solar radiation.

On this purpose there were previously observed the behavioural changes and there were determined the main physiological indexes, haematological indexes, the level of the thyroid hormones and in the end, the level of the antioxidant systems in blood and their correlation with milk production and quality changes.

The preliminary studies demonstrated that the month May represents the month for thermal comfort in cattle, which was considered in the study as reference month and August was the month when the cows were submitted to the most increased thermal stress.
The purpose of this paper is to observe if in dairy cattle, exposed to the solar radiation, could be noticed a certain reaction of the organism related to the oxidative stress, manifested by the increasing of the level of the antioxidant enzymes such as: superoxide dismutase (SOD), catalase and peroxidase in August comparing to May.

The main aim of this paper is to emphasise the direct and the indirect effects of caloric solar radiation on the status of health and milk production and quality in dairy cows in the climate conditions of Transylvania.

First of all, in order to have a better view, we present some considerations regarding the antioxidant systems in blood and ROS (Reactive Oxygen Species). The main ROS are: singlet oxygen, superoxyde radical anion, hydrogen peroxide and their radicals. 
Normally, the organism is protected by a large series of enzymatic antioxidants systems, which interact together. These are mainly represented by superoxide dismutase, catalase and peroxidases. These antioxidants systems have the role to control the forming and accumulation in the organism of the oxygen reactive species (ROS).

ROS may be formed in organism, both endogen and exogenous under the action of some physical or chemical agents (Dejica et al., 2000).

The solar radiation acts, also directly and indirectly by increasing the values of environmental temperatures. The most common index of heat stress (Temperature - Humidity Index - THI) is calculated using temperature and relative humidity (Yousef and Johnson, 1967).

$\mathrm{THI}=(1.8 \mathrm{xT}+32)-[(0.55-0.0055 \mathrm{xRH}) \mathrm{x}$ (1.8xT-26)] where $\mathrm{T}$ is Temperature and $\mathrm{RH}$ is Relative Humidity.

Dairy cows begin to suffer whenever the THI exceeds 72 (Jones and Stallings, 1999; West, 1995, 2000). Under these circumstances we recorded the forming, respective the accumulation in excess of the ROS which determines, so called "oxidative stress".

The oxidative stress is produced by the increasing of the free radicals or ROS production and/ or by the reduction of the antioxidant defense (Travisan et al., 2001, quot. by Bernabucci et al., 2002).

When the forming of the ROS rate increases, so that they cannot be further neutralised by the action of the antioxidants systems, the oxidative stress is produced (Sies, 1991, qout. by Bernabucci et al., 2002).

\section{Materials and methods}

The first changes to be noticed are those related to their behaviour. The observations regarding the behaviour changes were carried out on 87 cows and heifers on pasture and there were recorded behavioural accommodations in sense of thermogenesis' reduction (reduction of the voluntary motions and of the appetite) and of the thermolysis' intensification (intensification of perspiration and apparition of the thermal polypnea).

During the days of the experiment there were also recorded the meteorological data, such as: air temperature, relative humidity and there were calculated the maximum THI index values. The meteorological data registration was made in Meteorological Station belonging to USAMV ClujNapoca.

The determinations of the antioxidant enzyme's level were made in the Biochemistry Laboratory of the Faculty of Veterinary Medicine Cluj-Napoca. The determination of SOD was made using NBT method, based on pyrogallol oxidation in the presence of nitro blue tetrazolium chloride (NBT) resulting a stained product which can be photometric dosed at $540 \mathrm{~nm}$ (Ciurdaru, 2001). The catalase activity was analysed using a photometric method with potasium bichromate which is based on the reaction of the hydrogen peroxide with potassium bichromate. The peroxidase activity was analysed using a photometric method, based on the guayacol oxydation (Ciurdaru, 2001).

We correlated the phisyological changes of: SOD, peroxidase and catalase' s values recorded in May respectively August, with milk quality parameters: Fat, Proteins and Lactose.

The statistical processing were carryout in $R$.

\section{Results and discussions}

In May, the calculated values for maximum THI were lower than 72 , all the time of the day, varying between 43.4 and 67.5 , so they are within the limit for the thermal comfort in cows.

On the contrary, the mean of maximum THI index obtained in August was 78.03, being increased with $10.27 \%$ over the limit of 72 , which represents the limit over which the thermal discomfort appears in milking cows.

The experiments, previously made by us, presented an increasing of the main physiological indexes (such as respiratory rate, heart rate, internal and cutaneous temperature, variation of the blood indexes and thyroid hormones) determined us to study the reaction of the cows' organism at the cellular level, regarding the thermal stress.

Using $\operatorname{lm}$ function in $R$ we analysed the relationship between milk quality parameters (fat value, lactose value and protein value) and the stress indicators (SOD, catalase and peroxidase). We obtained a positive correlation between fat values and SOD values, $\mathrm{R}^{2}=0.64, \mathrm{p}<0.05$.

Also, we conclude that the parameters fat and catalase, respectively fat and peroxidase are significantly negative correlated, $\mathrm{R}^{2}=0.56$ respectively $R^{2}=0.95$. 
Table 1. Values of the antioxidant enzymes level (mean \pm SD) in August compared to May

\begin{tabular}{|c|c|c|c|c|c|c|}
\hline & \multicolumn{2}{|c|}{ SOD Activity $(\mathrm{U} / \mathrm{ml})$} & \multicolumn{2}{|c|}{ Catalase Activity (Ncat / ml) } & \multicolumn{2}{|c|}{$\begin{array}{c}\text { Glutation Peroxidase } \\
\text { Activity }(\mathrm{Px} / \mathrm{ml})\end{array}$} \\
\hline & May & August & May & August & May & August \\
\hline Mean $(\mathrm{X} \pm \mathrm{SD})$ & $30.57 \pm 7.28$ & $59.73 \pm 20.70$ & $1917.53 \pm 141.18$ & $3434.18 \pm 193.05$ & $70.58 \pm 15.62$ & $78.88 \pm 7.95$ \\
\hline
\end{tabular}

Table 2. Milk productions (mean \pm SD)/l/day and THI in August compared to May

\begin{tabular}{ccc}
\hline & May & August \\
\hline Milk productions (l / day) & $12.75 \pm 0.25$ & $8.64 \pm 0.41$ \\
\hline Maxim THI & 55.45 & 78.03 \\
\hline
\end{tabular}

Table 3. Milk quality parameters (mean \pm SD) in August compared to May

\begin{tabular}{|c|c|c|c|c|c|c|}
\hline & \multicolumn{2}{|c|}{ Fat $(\%)$} & \multicolumn{2}{|c|}{ Protein $(\%)$} & \multicolumn{2}{|c|}{ Lactose (\%) } \\
\hline & May & August & May & August & May & August \\
\hline Mean $(\mathrm{X} \pm \mathrm{SD})$ & $3.91 \pm 0.60$ & $3.40 \pm 0.52$ & $3.18 \pm 0.60$ & $2.97 \pm 0.60$ & $4.10 \pm 0.22$ & $4.04 \pm 0.21$ \\
\hline
\end{tabular}

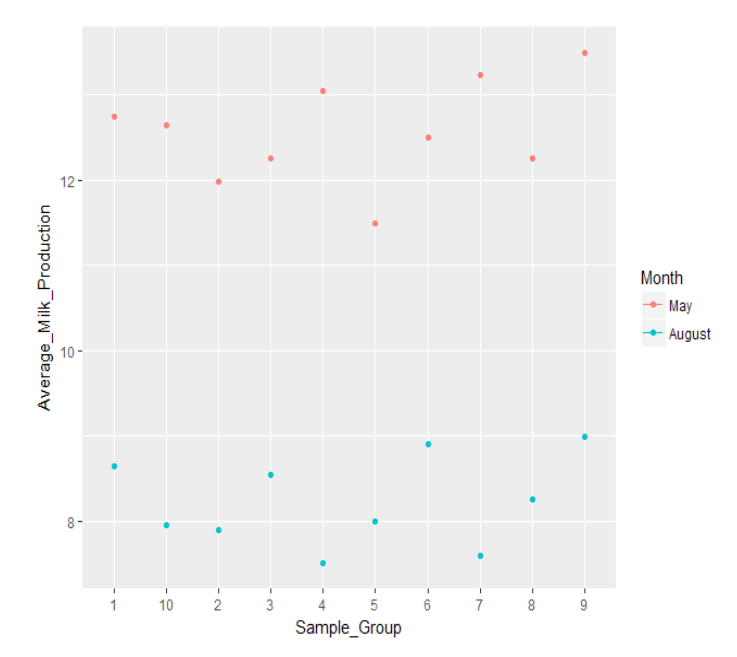

Figure 1. Milk production in May and August

Also, we note a negative significant correlation $(\mathrm{p}<0.05)$, between lactose and catalase $\mathrm{R}^{2}=0.56$, respectively betweeen lactose and peroxidase $\mathrm{R}^{2}=0.95$.

The parameters protein and catalase, respectively protein and peroxidase recorded negative significant correlation highlighted by correlation coefficients $\mathrm{R}^{2}=0.67$ respectively $\mathrm{R}^{2}=0.95$.

We note a negative significant correlation between milk production (l/day) recorded in May compared to milk production (1/day) recorded in August, $\mathrm{R}^{2}=0.94$ (Fig. 1). Also, we emphasize a significant difference between the mean milk productions recorded in May respectively in August.

The increasing of the antioxidant enzymes level proofs that, during the hot summer day, when the values of the THI index exceed the limit of 72 , the cows were submitted to the heat stress.

We can also surely say that between the increasing of the blood level of the antioxidants enzymes and the THI values exist a direct correlated relation, so that means that when the 
values of THI exceed 72, the production of the antioxidant enzymes at the blood level starts to increase.

The increasing of the antioxidants enzymes is due to the fact that in the animals organism the ORS are accumulated in the organism, by increasing the level of the antioxidant enzymes is trying to "neutralise" them. This can be explained by the hyperventilation which determines hyperoxia at the cell level and which is produced in the conditions of heat stress in cows.

Under the hyperoxia conditions is increased the level of lipids and protein oxidation, which determines the producing of ORS and as a consequence the level of the antioxidant enzymes increases.

\section{Conclusions}

During the hot summer days, when the values of THI exceed 72, the oxidative stress is produced in dairy cows, which is mainly manifested till the cellular level, by the increasing of the antioxidant enzymes activity. There was recorded a direct co-relation between the increasing of the antioxidant enzymes level and the increasing of the THI. There were recorded behavioural accommodations in sense of thermogenesis' reduction (reduction of the voluntary motions and of the appetite) and of the thermolysis' intensification (intensification of perspiration and apparition of the thermal polypnea).

It was recorded a positive correlation between fat values and SOD values, $R^{2}=0.64, p<0.05$. If we consider also the parameter Month, $\mathrm{R}^{2}=0.67$, $\mathrm{p}<0.05$, contributes with $3 \%$ to the Fat decrease values. Parameters fat and catalase are negative correlated, $\mathrm{R}^{2}=0.56$. Parameter Month contributes with $6 \%$ to the Fat level's decrease. Between the parameters fat and peroxidase we recorded a significantly negative correlation, $\mathrm{R}^{2}=0.95$.

Acknowledgments. This research did not receive any specific grant from funding agencies in the public, commercial, or not-for-profit sectors.

\section{References}

1. Bernabucci U, Ronchi B, Lacetera N, Nardone A (2002). Markers of Oxidative Status in Plasma and Erythrocytes of Transition Dairy Cows During Hot Season, Journal of Dairy Science 85: 2173- 2179.

2. Ciurdaru V, Andrei S, Pintea A, Bele C (2001). Biochimie medicală veterinară - metode şi tehnici de laborator, Editura AcademicPres, Cluj-Napoca.

3. Dejica D (2000). Stresul oxidativ în bolile interne, Editura Casa Cărţii de Ştiinţă, Cluj-Napoca.

4. Yousef MK, Johnson HD (1967). Physiological Thermoneutrality Zones of Cattle, Biometeorology 2(I): 477-484.

5. Jones GM, Stallings CC (1999). Reducing Heat Stress for Dairy Cattle, Virginia Cooperative Extension, Publication No. 404-200.

6. Murphy MP, Holmgren A, Larsson NG, Halliwell B, Chang CJ (2011). Unraveling the biological roles of reactive oxygen species. Cell Metab. 13: 361-366.

7. Nikkhah A, Kowsar R (2012). Seasonal and group effects on dairy cow behavior in large yards.Turk J Vet Anim Sci 36(2): 123-129.

8. www.r-project.org 